\title{
Green Tourism Innovation Through the Application of Environment Management Accounting
}

\author{
$1^{\text {st }}$ Ayu Dwi Yuliathi \\ Tourism Departement \\ Bali State Polytechnic \\ Jimbaran, Bali, Indonesia \\ dwiyulianthi@pnb.ac.id
}

\author{
$2^{\text {nd }}$ Putu Wiwiek Ary Susyarini \\ Tourism Departement \\ Bali State Polytechnic \\ Jimbaran, Bali, Indonesia \\ putuwiwiekarysusyarini@pnb.ac.id
}

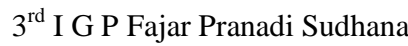 \\ Tourism Departement \\ Bali State Polytechnic \\ Jimbaran, Bali, Indonesia \\ fpranadi@pnb.ac.id
}

\begin{abstract}
In this current era of modern economy, there is a wide range of issues related to the environment, such as global warming, eco-efficiency, and industrial activity that give a direct impact on the surrounding environment. This case has created a change in the corporate environment, both internally and externally. Therefore, management accounting environment required by each company to provide information to companies related to the environmental performance of the company. In contrast to the concept of conventional accounting, the managerial environment aims at increasing the amount of relevant information required as an indicator of making a decision. Nowadays, some hotels in Bali is doing business based on the impact that occurred from a process. As a matter of fact, it is characterized by a growing number of hotels that has already awarded Tri Hita Karana. This research uses research from respondents obtain Tri Hita Karana Awards because the writers wanted to examine whether policies that management take this for sustainable development is in compliance with the principles in accounting Environmental management (EMA) where the application of the EMA will produce a variety of relevant information so that management is not wrong in taking decisions related to sustainable development. Analytical techniques used are qualitative analysis techniques.
\end{abstract}

Keywords - The Eco-Efficiency Innovation, Green Tourism, Environmental Management Accounting

\section{INTRODUCTION}

In the era of modern economy as currently, there is a wide range of issues related to the environment such as global warming, eco-efficiency, and industrial activity that gives a direct impact on the surrounding environment has created a change in the corporate environment, both internal and external. The existence of the facts of the problem of environmental pollution made by companies in Indonesia led to a business environment must be able to sustain its business processes so companies should implement appropriate strategies for the sake of someone else going concern companies as well as sustainable development. In Bali, the environmental problems due to the company's production process is found for example in the case of environmental pollution that causes a decrease in the levels of water quality in the vicinity of industry adjacent to the houses. Another example is the case of air pollution due to excessive use of Air Conditioning. The environmental policies adopted by many countries during the last 25 years have shown evolution anyway. Originally a company will establish a policy that focuses on things that tend to be associated with the direct impact of a company's business processes such as cleaning up pollution that exists and try to reduce pollution from point sources disposal management strategy, then moved toward modification of the production process so as to minimize the amount of pollution produced (Purwanto, 2007). In managing the company, managers must make a decision that is considering carefully from a variety of alternative actions and choosing the best course of action to achieve a goal that has been planned (Daljono, 2004).

As for the underlying reasons why an organisation and accountant should care among other environmental problems: many corporate stakeholders from both the internal and external sides showed an increase his interests against environmental performance of an organization (Ikhsan 2009:3). Some other reasons is the regulation on the environment have increased as the signing of a memorandum of understanding (Mou) with the environmental protection agency (EPAEnvironmental Protection Agency) in Jakarta in June 2011. The existence of a variety of policies in the field of environment which then becomes the beginning of the development of a concept that aims to find solutions to business objectives and the fulfillment of the resolution of environmental issues called eco-efficiency. This principle study how organizations can produce goods and services more usable, while simultaneously reducing the negative environmental impact of resource consumption, as well as costs, through improvements in efficiency that comes from This concept of environmental performance improvements to contain at least three important messages. First, the performance improvement of ecology and economy complement each other. Second, improvements in environmental performance that should not be seen as charity and charity but rather competition, and thirdly, eco-efficiency is a complement and supports sustainable development (Mowen 1990: 70). Therefore, Environmental Management Accounting is needed by each company to provide information to companies related to the company's environmental performance. In contrast to conventional accounting concepts, environmental management accounting aims to increase the amount of information relevant to those who need it, so that it can be used as an indicator of decision making. The success of environmental accounting does not only depend on the accuracy in classifying all costs made by the company. 
However, the ability and accuracy of the company's accounting data in suppressing the environmental impacts arising from company activities (Ikhsan 2009: 21). The importance and magnitude of the risks associated with sustainability encourage the need to find new control methods, especially to create transparency regarding economic, environmental and social impacts for stakeholders (GRI, 2006). In supporting this expectation, it is appropriate to encourage a company to carry out business processes by paying attention to the impact that will occur from the process. Innovation towards green tourism through the application of environmental management accounting must be carried out considering that one of the challenges of sustainable development is the demands and choices for new ways of thinking. Sustainable development aims to meet the needs of the present without reducing the ability to meet the needs of future generations (Commission on Environment and Development (in GRI, 2006). Through the application of environmental management accounting, it will produce information related to relevant environmental impacts. a business innovates better in terms of products, processes and costs By innovating, the company will obtain various benefits not only focusing on the market (externally), but also on the benefits within the company itself (internal). In Bali, one of the businesses that causes a negative impact on the surrounding environment is business in the accommodation sector. Some Hotels in Bali lately also do business processes by starting to pay attention to the impact of the process. This is indicated by the increasing number of Hotels who want or have received the Tri Hita Karana award. The Tri Hita Karana Award is obtained for Hotels that carry out their business activities while still taking into account the environmental impact of these activities and trying to reduce the negative impacts that occur. This study uses research respondents from hotels that obtained the Tri Hita Karana Award because the authors want to examine whether the policies that management takes for sustainable development are in accordance with the principles in Environmental Management Accounting (EMA) where the application of EMA will produce various relevant information so that management not wrong. in making decisions related to sustainable development.

\section{A. Problem formulation}

Based on the above background, the formulation of the problem in this study is how green tourism innovation through the application of environmental management accounting at the Tri Hita Karana Award winning hotel in the Nusa Dua area.

\section{B. Literature Review}

\section{a. Environmental Management Accounting} (Environmental Management Accounting)

It is one of the sub-systems of environmental accounting that explains a number of issues concerning the issue of quantifying the impacts of a company's business into a number of monetary units. Environmental management accounting can also be used as a benchmark in environmental performance. Environmental Management Accounting and Business Strategy
The application of EMA in an organization is likely to be influenced by business strategies. Management control systems (SPM) ensure that managers use available resources effectively and efficiently in achieving organizational goals (Anthony, 1965). Thus, SPM designed to meet organizational needs contributes to achieving superior performance (Dent, 1991; et al. Simson, 1991; Simons, 1987, 1990, 1995b in Ferreira et al, 2009). On the other hand, EMA is a technique that emphasizes efficiency and effectiveness in resource use and is part of a broader management control system. the consequence of this statement is that if the strategy is the determinant of the management control system, then it is likely that it will also affect the extent of the use of EMA.

\section{b. Environmental Costs}

Environmental costs are costs that occur due to poor environmental quality or due to poor environmental quality that may occur. Thus, environmental costs relate to the creation, detection, repair and prevention of environmental degradation. With this definition, environmental costs can be classified into four categories: prevention costs, detection costs, internal failure costs, and external failure costs.

\section{c. Cost of environmental products}

Environmental costs of the process of producing, marketing and delivering products and post-purchase environmental costs caused by product use and disposal are examples of environmental product costs. Imposing environmental costs on products can produce useful managerial information. By appropriately charging environmental costs, it will be known whether a product is profitable or not. If it is not profitable, the product can be stopped to achieve significant improvements in environmental performance and economic efficiency.

\section{d. $\quad$ Target Costing}

Target costing is the determination of the expected costs for a product based on competitive prices so that the product earns profit as expected. The company has two choices to reduce costs up to the target cost, namely:

1. By integrating new technology, using sophisticated cost management techniques and seeking higher productivity through improved organization and labor relations, companies will be able to reduce costs. This approach is implemented by determining standard costs (standard costing).

2. By redesigning the product or service, the company can reduce costs until it reaches the target costing level. This method is more common because it recognizes that design decisions have a large influence on total costs during the product life cycle. by paying careful attention to the design it is possible to significantly reduce total costs. 


\section{RESEARCH METHOD}

\section{A. Location and respondents}

The study was conducted at hotels that received the 2017 Tri Hita Karana Award in the Nusa Dua area. The reason for choosing this hotel as a respondent is because this hotel includes hotels that have implemented the concept of environmentally friendly although environmental management accounting is not yet fully implemented. The respondents in this study were Melia Bali Hotel.

\section{B. Data collection technique}

\section{Interview}

In-depth interviews will be conducted by the author with the management and accounting departments in each hotel regarding green tourism innovation through the application of environmental management accounting.

\section{Observation}

Observations will be made by the author by looking at the system and recording of financial reporting held by the hotel whether there are already components needed to implement environmental management accounting.

\section{Data Types}

The data used in this study are primary data and secondary data. The explanation is as follows. :

\section{Primary Data}

The primary data used by the researcher are: the results of the interview in accordance with the item of question, the results of the interview with the manager regarding the application of environmental management accounting, and so on.

2. Secondary data

Secondary data used by researchers in this scientific work are literature on environmental management accounting, general description of the company, organizational structure.

\section{Data Analysis Techniques}

Data analysis techniques used in this study are qualitative analysis techniques, namely the process of activities which include recording, organizing, grouping and synthesizing data, then interpreting each category of data, searching for and finding patterns, relationships and describing findings in the form of narrative descriptions, charts , flowcharts, matrices and images that can be understood and understood by others.

\section{E. Research Design}

Research will be conducted at the hotel that receives the Tri Hita Karana Award in the Nusa Dua Region regarding green tourism innovation through the application of environmental management accounting in its financial report notes as a form of responsibility for the surrounding environment and begins to introduce concepts from environmental accounting to management in each hotel. The data collection technique is to conduct interviews with hotel management and hotel employees, especially in the field of accounting and observation to see the recording of financial statements applied by the company. In the research activity, concepts from environmental management accounting will be introduced to management and hotel employees. As well as the model of the application of environmental management accounting has begun to be compiled and tested to respondents who are the research sample.

The aspects that will be discussed and studied in the environmental accounting application model are as follows:

1. Recognition and identification of the negative effects of the company's business activities on the environment in conventional environmental management accounting practices.

2. Identify, search for and examine field issues to work on environmental management accounting that are contrary to environmental criteria and provide an alternative solution.

3. Implement proactive steps in developing initiatives to improve the environment in environmental management accounting practices.

4. Development of a new format for environmental management accounting systems, environmentally friendly management decision support control systems.

5. Identification of costs and benefits in the form of revenue if the company is more concerned about the environment from various environmental improvement programs.

6. Development of work formats, internal and external assessment and reporting of the company

7. Continuous corporate efforts, accounting for liabilities, risks, investment costs on energy, waste and environmental protection.

8. Development of accounting techniques on assets, liabilities and costs in the context of non-financial, especially ecological.

\section{RESULT AND DISCUSSION}

\section{A. Environmental Cost}

Based on the results of interviews and data collection at the Melia Bali Hotel related to environmental accounting performance, there are several explanations that need to be disclosed related to the costs or costs associated with the application of environmental accounting:

1. Costs for treating liquid waste

That Wastewater Treatment resulting from various hotel activities and supporting facilities located in the Nusa Dua Tourism Area, is channeled through underground pipelines distributed and accommodated in a centralized wastewater treatment pond (Scientific Oxidation) called Lagoon . Pond / Lagoon is built on a land area of $17 \mathrm{Ha}$, with a Wastewater Treatment System (Stabilization Pool), which 
only uses a System of Control and Flow of Wastewater from one Pool to the next. From this wastewater treatment process, recycle water is produced which water is classified as Irrigation Water, which is used for watering hotel, golf and all park areas in the Nusa Dua Tourism Office. The costs incurred each year are Rp. 25,000,000 for maintenance of the equipment used.

2. Costs for treating solid waste

The costs incurred for processing solid waste are the costs of collecting waste carried out by third parties amounting to Rp. 200,000 per month

Social Security costs given to employees.

3. Labor safety costs such as the provision of First Aid (P3K) tools.

4. Garden maintenance costs and tree planting

5. Beach cleaning costs

6. Cost of supplier feasibility testing

7. Cost of checking carbon emissions.

Costs associated with environmental activities are known, but each activity has not been grouped according to the existing environmental quality cost categories. From the data above, the researcher will classify environmental activity costs according to the environmental quality cost category based on Hansen and Mowen's (2009) theory of prevention costs, detection costs, internal failure costs, and costs external failure cost. The following are four environmental quality categories related to activities at Melia Bali:

1. Environmental Prevention Costs

That is the cost for activities carried out to prevent the production of waste or waste that can damage the environment. The most dense environmental prevention cost at Melia Bali is the cost of treating liquid waste, the costs of treating solid waste, the cost of social security, labor safety costs, garden maintenance costs and tree planting, and the cost of cleaning beaches.

\section{Environmental Detection Costs}

Is a fee for activities carried out to determine that products, processes and other activities in the company meet applicable environmental standards or not. The cost of environmental detection contained in Melia Bali is the cost of the supplier's feasibility test, where suppliers who want to supply food ingredients are tested in advance the quality of the food ingredients whether they are environmentally friendly products or not. The next cost of environmental detection is the cost of checking carbon emissions, Melia Bali calculates the carbon emissions issued if there are foreign guests who come to the hotel to stay with the aim of knowing the level of pollution produced will then be planted in accordance with the amount of carbon emissions issued.

3. Internal Failure Costs

Are costs for activities carried out because of the production of waste and waste, but are not disposed of outside. In the case that happened at Melia Bali there was no failure fee which caused a loss to Melia Bali from its environmental activities.

4. External Failure Costs

Are costs for activities carried out after removing waste or garbage into the environment. In the case that happened at Melia Bali there was no failure fee which caused a loss to Melia Bali from its environmental activities.

The following is a comparison between the environmental costs incurred by Melia Bali with the existing theories (Hansen and Mowen).

TABle 1 Cost Comparison Between Hansen And Mowen with Melia BaLI

\begin{tabular}{|c|c|c|c|}
\hline No & Information & Hansen dan Mowen & Melia Bali \\
\hline \multirow[t]{8}{*}{1} & \multirow[t]{8}{*}{ Prevention Costs } & Evaluate and select suppliers & Supplier feasibility test costs \\
\hline & & Evaluate and choose tools to control pollution & The cost of processing liquid waste \\
\hline & & Designing products. & \\
\hline & & Carry out environmental studies & Jamsostek costs and employee safety \\
\hline & & Audit environmental risks & \\
\hline & & Develop an environmental management system & $\begin{array}{l}\text { Garden arrangements costs, garden } \\
\text { maintenance costs, beach cleaning costs }\end{array}$ \\
\hline & & Recycling products & Solid waste processing costs \\
\hline & & Obtained ISO 14001 certification & \\
\hline \multirow[t]{10}{*}{2} & \multirow[t]{6}{*}{ Detection Costs } & Audit environmental activities & \\
\hline & & Check products and processes & \\
\hline & & Develop measures of environmental performance & \\
\hline & & Testing Pollution & The cost of measuring carbon emissions \\
\hline & & Verify performance & \\
\hline & & Measure the level of pollution & \\
\hline & \multirow{4}{*}{$\begin{array}{l}\text { Internal Failure } \\
\text { Cost }\end{array}$} & Operate pollution control equipment & \\
\hline & & Processing and disposing of toxic waste & \\
\hline & & Maintain pollution equipment & \\
\hline & & Obtain a facility license to produce waste & \\
\hline
\end{tabular}




\begin{tabular}{|c|c|c|c|}
\hline & & Recycle remaining ingredients & \\
\hline \multirow[t]{11}{*}{4} & \multirow{11}{*}{$\begin{array}{l}\text { External failure } \\
\text { costs }\end{array}$} & Clean up polluted lakes & \\
\hline & & Clean up spilled oil & \\
\hline & & Clean up contaminated soil & \\
\hline & & Complete personal accident claims related to the environment & \\
\hline & & Restoring the soil to its natural state & \\
\hline & & Loss of sales due to bad environmental reputation & \\
\hline & & Using raw materials and electricity inefficient & \\
\hline & & Receive medical treatment due to air pollution & \\
\hline & & Job loss due to pollution & \\
\hline & & The loss of the benefits of the lake as a place of recreation & \\
\hline & & $\begin{array}{l}\text { Damage to the ecosystem due to the disposal of solid and liquid } \\
\text { waste }\end{array}$ & \\
\hline
\end{tabular}

Source: Internal Melia Bali, 2018

From the results of the identification of environmental costs that have been made by Melia Bali, the report on environmental costs according to Research Setyaningtyas and Andono (2013) is important if the company is serious about improving environmental performance and controlling environmental costs. According to Setyaningtyas and Andono (2013), the steps in making environmental cost reports are:

1. Provide details of environmental costs according to classification

2. Entering the details of the costs into the environmental cost report is accompanied by a percentage in each classification

This analysis will compare again the stages that Melia Bali will do with the generally accepted principles:

1. Identification

The identification made by Melia Bali in carrying out the stages of environmental cost treatment, especially waste management, is treated as other costs. Other costs means the costs incurred by the company in handling environmental management that are not specifically treated in the accounts of financial statements.

2. Recognition

Melia Bali recognizes the cost element as other costs in the financial statements. These costs are used for environmental operations.

3. Measurement

Melia Bali in measuring the value and amount of costs incurred for financing this environment with reference to the realization of the previous period's budget. Melia Bali assumes that the budget realization of the past period is a valid experience lesson to be used as a reference in determining the value and amount of costs incurred in environmental management in one period.

4. Presentation

Melia Bali presents the allocation of environmental costs together with the costs of other allied units. The presentation is carried out together as sub-sub-costs in other expense accounts.

5. Disclosure

Melia Bali revealed that accounting finance in financial statements adheres to the normative model, meaning that disclosure of environmental costs does not require a special presentation in the financial statements.

\section{CONCLUSION}

In managing costs related to environmental preservation, Melia Bali still unites these costs in one account. Therefore the authors identify these costs into 4 environmental quality cost categories namely prevention costs, detection costs, internal failure costs, and external failure costs. For prevention costs include the cost of processing liquid waste, costs for processing solid waste, social security costs, labor safety costs, garden maintenance costs and tree planting, and the cost of cleaning the beach. Detection costs include supplier feasibility testing costs and carbon emissions checking costs. For internal failure costs and external failure costs, Melia Bali does not incur these costs

\section{REFERENCES}

[1] Gibson, Ivancevich, Donelly. 2000. Organisasi, Perilaku, Struktur, Proses (Alih Bahasa: Djakarsih). Edisi Keenam. Jakarta: Penerbit Erlangga.

[2] International Accounting Standards Board, 2004, Discussion Paper: Preliminary views on Accounting Standards For Small and Medium sized Entities, IASB, London, United Kingdom.

[3] Margani Pinasti, 2007, Pengaruh Penyelenggaraan dan Penggunaan Informasi Akuntansi Terhadap Persepsi Pangusaha Kecil atas Informasi akuntansi: Suatu Riset Eksperimen, Simposium Nasional Akuntansi (SNA) ke X, Makassar.

[4] Megginson, W.L., M.J. Byrd,and L.C. Megginson, 2000, Small Business Management: An Entrepreneur's Guidebook, Third Edition, Irwin McGraw-Hill, Bosyon.

[5] Metzler, J.C., 2005 ,How the AICPA Help Members Serve Small Business, Journal of Accountancy, 199 (march)

[6] Murniati, 2002. Investigasi Faktor-Faktor Yang Mempengaruhi Penyiapan dan Informasi Akuntansi Perusahaan Kecil dan Menengah. Simposium Fakultas Ekonomi Universitas Corkrominoto Yogyakarta.

[7] Pinasti, M., 2001, Penggunaan Informasi akuntansi dalam penegelolaan Uasa Para Pedagang Kecil di Pasar Tradisional Kabupaten Banyumas, Jurnal Ekonomi Bisnis dan Akuntansi, NO.1/Vol3/ Mei

[8] Pinasti, Margani. 2007. Pengaruh Penyelenggaraan Dan Penggunaan Informasi Akuntansi Terhadap Persepsi Pengusaha Kecil Atas Informasi Akuntansi : Suatu Riset Eksperimen. Makasar : SNA X 